\title{
Study of Palmar Dermatoglyphics in Mentally Retarded Children
}

\author{
Dr.Vaishali B. Bhagwat ${ }^{1}$, Dr. Mrs. M.M.Meshram ${ }^{2}$ \\ ${ }^{1}$ (Department of Anatomy, SRTR Government Medical College, Ambajogai/MUHS Nashik Maharashtra, India) \\ ${ }_{2}^{2}$ (Department of Anatomy, Government Medical College, Nagpur/MUHS Nashik Maharashtra, India)
}

\begin{abstract}
Astract: A state of mental retardation may be produced by various endogenous and exogenous influences acting independently or in concert with each other. Recently dermatoglypic patterns have been utilized as a diagnostic tool in various disorders like mental retardation. The study comprising of 400 subjects (200 mentally retarded, 200 controls) was carried out in the Department of Anatomy Government Medical College, Nagpur.

The present study was undertaken to evaluate the dermatoglyphic features in the mentally retarded children. The features which showed significant variations in mentally retarded children included: low total finger ridge count (TFRC), higher ATD angle, and distal displacement of axial Triradius, an increased frequency of Simian crease and Sydney line.
\end{abstract}

Keywords- Dermatoglyphics, Loops, Mentally Retardation, Simian Crease, Whorls,

Submitted date 29 May 2013

Accepted Date: 04 June 2013

\section{Introduction}

Dermatoglyphics is the scientific study of epidermal ridges and their configuration on palmar \& plantar region. The dermal ridges are differentiated in their definitive forms during $3^{\text {rd }}$ and $4^{\text {th }}$ month of fetal life and completed by $7^{\text {th }}$ month. Once fully formed, except for change in size, they never change pattern either in the remaining intrauterine life or after birth [1]. Dermatoglypic patterns are genetically determined. The mentally retarded in great numbers and in dire need, have remained until this decade among the most ignored and least regarded of all children.

Taking into consideration the genetic predisposition of dermatoglyphics and mental retardation, the present study was undertaken to evaluate the dermatoglypic features \& note any specific variations or diagnostic feature in mentally retarded children.

Mental retardation means mental illness, arrested or incomplete development of mind. It is a condition of sub average intellectual function combined with deficits in adaptive behavior [2].

The etiological factors contributing to human developmental problems may be prenatal, perinatal and postnatal. There may be environmental, physiological, sociocultural, genetic risk factors.

In this study, the dermatoglypic patterns of mentally retarded children were compared with controls. An attempt is made to find out whether a specific dermatoglypic trait exists in mental retardation and if so, whether it is significant or not.

\section{Material And Methods}

The present study was carried out in the department of Anatomy, Government Medical College and Hospital, Nagpur. Patients selected for the study were already diagnosed cases of mental retardation due to various causes. The study comprised of a total 400 subjects (200 mentally retarded and 200 controls) in the age group of 4 to 12 years. There were 100 males and 100 females in each group.

The palmar prints of subjects and control were taken on the Map Litho white paper by 'INK' method as described by Cummins \&Midlo [1]. Kores Camel duplicating ink was spread over an inking slab of size 12" by 8 " made of plain glass. Both hands were washed with soap and water. After soaking, the palm and fingers were placed on the inking slab. The smeared palm and fingers of both hands were then kept on the white paper with firm pressure on the dorsum of hand and interdigital area. The dermatoglyphic patterns were thus recorded and the following parameters were studied.

1. Qualitative analysis of fingerprints -Whorls, Loops and Arches.

2. Quantitative analysis of fingerprints - TFRC (Total Finger ridge Count),

- AFRC (Absolute Finger Ridge Count).

3. Palmar patterns

4. Axial Triradii

5. 'atd' angle

6. Sydney Line \& Simian Line 
The dermatoglyphic patterns on right and left hand were analyzed according to sex and were subjected to statistical test to evaluate significant pattern.

\section{Observation And Results}

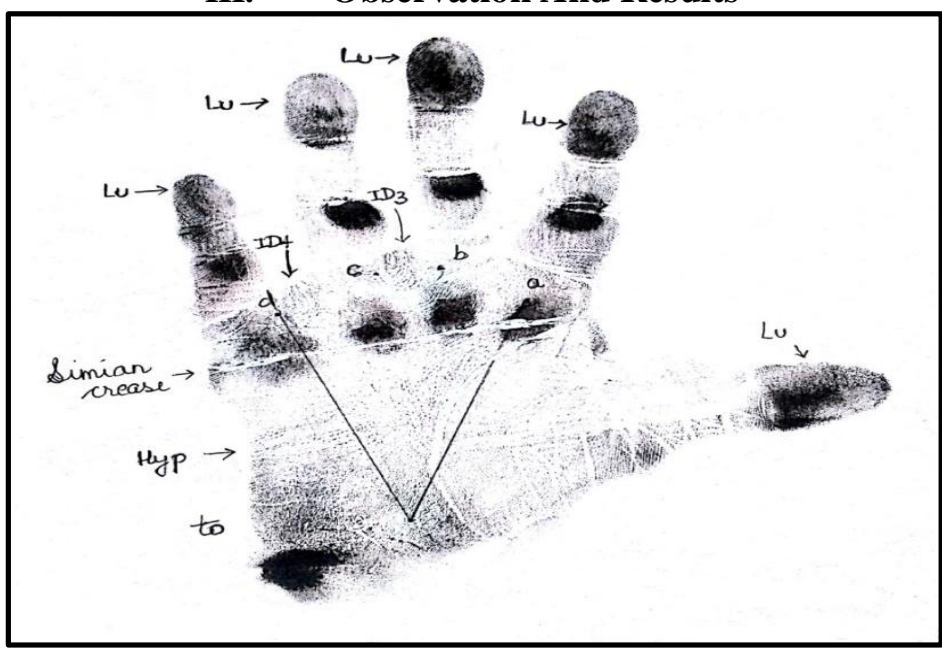

Figure No. 1: Imprint of a mentally retarded male showing

1. Fingertip pattern on all digits (Lu).

2. True palmar patterns in ID3, ID4 and hypothenar areas.

3. Simian Crease

The dermatoglypic patterns were analyzed according to sex and were subjected to nonparametric statistical tests to evaluate significant pattern of identifiable differences between mentally retarded and controls.

TABLE no. 1- Total cases of each group and sex distribution

\begin{tabular}{|l|l|l|l|}
\hline SUBJECTS & MALE & FEMALE & TOTAL \\
\hline $\begin{array}{l}\text { MENTALLY } \\
\text { RETARDED }\end{array}$ & 100 & 100 & 200 \\
\hline CONTROL & 100 & 100 & 200 \\
\hline
\end{tabular}

The above TABLE shows number of cases of each group and sex distribution.

TABLE no.2: Percentagewise distribution of Fingertip pattern in mentally retarded children and controls

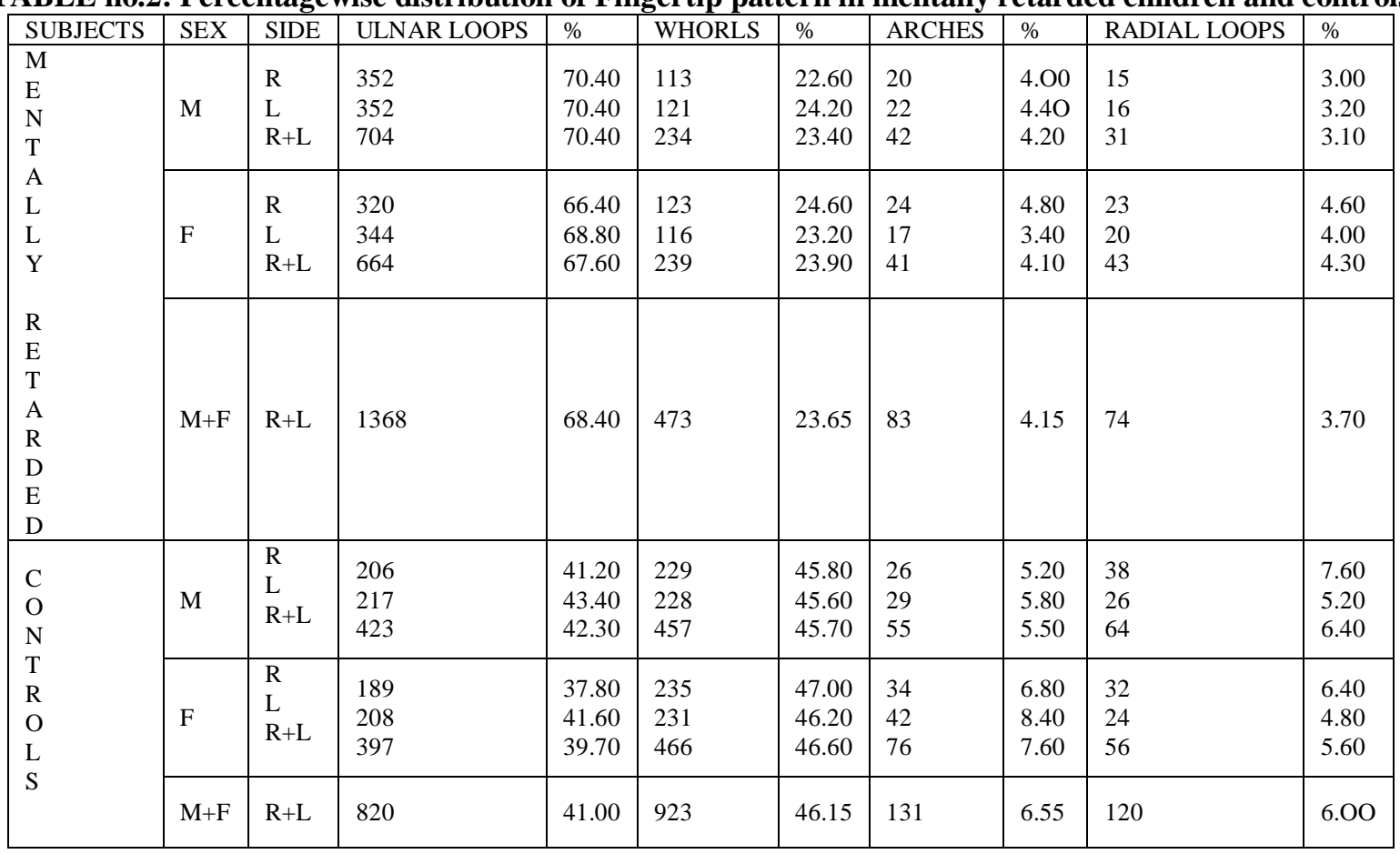


This TABLE shows that there is higher incidence of ulnar loops $(68.4 \%)$, decreased incidence of whorls $(23.65 \%)$, arches $(4.15 \%)$ and radial loops in mentally retarded children when compared with control. The ulnar loop patterns are significantly increased on little and middle finger in male and female mentally retarded children, but whorls, arches and radial loops are significantly reduced in both sexes than in controls.

TABLE 3: Statistical calculation for TFRC

\begin{tabular}{|l|l|l|l|l|l|}
\hline SUBJECT & SEX & $\overline{\mathbf{x}}$ & S.D. & S.E. of $\overline{\mathbf{x}}$ & $\mathbf{C . V . \%}$ \\
\hline \multirow{2}{*}{$\begin{array}{l}\text { MENTALLY } \\
\text { RETARDED }\end{array}$} & $\mathrm{M}$ & 122.80 & 53.33 & 5.33 & 43.43 \\
\cline { 2 - 6 } & $\mathrm{F}$ & 119.49 & 45.52 & 4.55 & 38.10 \\
\cline { 2 - 6 } & $\mathrm{M}+\mathrm{F}$ & 120.53 & 49.43 & 3.49 & 41.01 \\
\hline \multirow{3}{*}{ CONTROLS } & $\mathrm{M}$ & 142.04 & 55.08 & 5.50 & 38.78 \\
\cline { 2 - 6 } & $\mathrm{F}$ & 128.91 & 48.20 & 4.82 & 37.39 \\
\cline { 2 - 6 } & $\mathrm{M}+\mathrm{F}$ & 135.47 & 52.28 & 3.69 & 38.59 \\
\hline
\end{tabular}

Total finger ridge count (TFRC): Mean with standard deviation of total finger ridge count were separately calculated and compared between two groups. The values in mentally retarded were males and females were $122.80 \&$ in 119.49 respectively. The values in control of males and females were $142.04 \&$ 128.91.The difference between means of two groups in males was statistically significant whereas in females of both groups, the difference between mean of TFRC was statistically insignificant.

Index:- $\mathrm{X}$-Mean value

S.D.-Standard Deviation

S.E. of X-Standard Error of Mean

C.V.-Coefficient of Variation (in \%)

TABLE 4: The incidence of presence of palmar pattern in interdigital areas including thenar and hypothenar areas

\begin{tabular}{|c|c|c|c|c|c|c|c|c|c|c|c|c|}
\hline SUBJECT & SEX & $\begin{array}{l}\text { SID } \\
\text { E }\end{array}$ & $\begin{array}{l}\text { HYP } \\
\mathrm{O}\end{array}$ & $\%$ & $\begin{array}{l}\text { TH/ID } \\
1\end{array}$ & $\%$ & $\begin{array}{l}\text { ID } \\
2\end{array}$ & $\%$ & ID3 & $\%$ & ID4 & $\%$ \\
\hline \multirow{6}{*}{$\begin{array}{l}\text { MENTALL } \\
\text { Y } \\
\text { RETARDE } \\
\text { D }\end{array}$} & \multirow{3}{*}{ M } & $\mathrm{R}$ & 38 & 38 & 04 & 4 & 5 & 5 & 28 & 28 & 47 & 47 \\
\hline & & $\mathrm{L}$ & 41 & 41 & 05 & 5 & 7 & 7 & 21 & 21 & 43 & 43 \\
\hline & & $\mathrm{R}+\mathrm{L}$ & 79 & $\begin{array}{l}39 \\
.5\end{array}$ & 09 & 4.5 & 12 & 6 & 49 & 24.5 & 90 & 45 \\
\hline & \multirow{3}{*}{$\mathrm{F}$} & $\mathrm{R}$ & 31 & 31 & 03 & 3 & 8 & 8 & 21 & 21 & 31 & 31 \\
\hline & & $\mathrm{L}$ & 23 & 23 & 03 & 3 & 6 & 6 & 12 & 12 & 27 & 27 \\
\hline & & $\mathrm{R}+\mathrm{L}$ & 54 & 27 & 06 & 3 & 14 & 7 & 33 & 16.5 & 58 & 29 \\
\hline \multirow{6}{*}{$\begin{array}{l}\text { CONTROL } \\
\mathrm{S}\end{array}$} & \multirow{3}{*}{ M } & $\mathrm{R}$ & 09 & 09 & 05 & 5 & 14 & 14 & 26 & 26 & 39 & 39 \\
\hline & & $\mathrm{L}$ & 14 & 14 & 10 & 10 & 16 & 16 & 16 & 16 & 36 & 36 \\
\hline & & $\mathrm{R}+\mathrm{L}$ & 23 & $\begin{array}{l}11 \\
.5\end{array}$ & 15 & 7.5 & 30 & 15 & 42 & 21 & 75 & 37.5 \\
\hline & \multirow{3}{*}{$\mathrm{F}$} & $\mathrm{R}$ & 06 & 06 & 04 & 4 & 13 & 13 & 27 & 27 & 20 & 20 \\
\hline & & $\mathrm{L}$ & 10 & 10 & 02 & 2 & 14 & 14 & 18 & 18 & 20 & 20 \\
\hline & & $\mathrm{R}+\mathrm{L}$ & 16 & 08 & 06 & 3 & 27 & 13.5 & 45 & 22.5 & 40 & 20 \\
\hline
\end{tabular}

HYPO - Hypothenar, \% - Percentage, TH -Thenar, ID - Interdigital areas.

TABLE 4 shows percentage wise incidence of pattern in main 5 palmar areas. In male mentally retarded children, the percentage of palmar pattern is $45 \%$ in the fourth interdigital area, $24.50 \%$ in third interdigital area and $39.50 \%$ in hypothenar area. Whereas, in male controls, the palmar pattern is $37.5 \%$ in the fourth interdigital area, $21 \%$ in third interdigital area and $11.5 \%$ in hypothenar area.In case of female mentally retarded children, it is found to be $29 \%$ in the fourth interdigital area, $27 \%$ in hypothenar area whereas in female control palmar pattern is $20 \%$ in the fourth interdigital area and $8 \%$ in hypothenar area.

TABLE no 5: Frequency distribution of different positions and percentage of distal displacement of axial triradii in mentally retarded children and controls

\begin{tabular}{|c|c|c|c|c|c|c|c|c|c|c|c|c|c|}
\hline SUBJECT & SEX & \multicolumn{2}{|l|}{ TO } & \multicolumn{2}{|l|}{$\mathrm{T} 1$} & \multicolumn{2}{|l|}{$\mathrm{T} 2$} & \multicolumn{2}{|c|}{ T0T1 } & \multicolumn{2}{|c|}{ T0T2 } & \multicolumn{2}{|c|}{ T1T2 } \\
\hline \multirow{4}{*}{$\begin{array}{l}\text { MENTALLY } \\
\text { RETARDED }\end{array}$} & & No. & $\%$ & No. & $\%$ & No. & $\%$ & No. & $\%$ & No. & $\%$ & No. & $\%$ \\
\hline & $\mathrm{M}$ & 100 & 50.00 & 72 & 36.00 & 09 & 4.50 & 02 & 1.00 & 07 & 3.50 & 12 & 6.00 \\
\hline & $\mathrm{F}$ & 78 & 39.00 & 72 & 36.00 & 08 & 4.00 & 07 & 3.50 & 03 & 1.50 & 03 & 1.50 \\
\hline & $\mathrm{M}+\mathrm{F}$ & 178 & 44.50 & 148 & 37.00 & 17 & 4.25 & 09 & 2.25 & 10 & 2.50 & 15 & 3.75 \\
\hline \multirow{3}{*}{ CONTROLS } & $\mathrm{M}$ & 162 & 81.00 & 30 & 15.00 & 01 & 0.50 & 04 & 2.00 & 03 & 1.50 & 00 & 00 \\
\hline & $\mathrm{F}$ & 157 & 78.50 & 27 & 13.50 & 02 & 1.00 & 06 & 3.00 & 08 & 4.00 & 00 & 00 \\
\hline & $\mathrm{M}+\mathrm{F}$ & 319 & 79.75 & 57 & 14.25 & 03 & 0.75 & 10 & 5.00 & 11 & 2.75 & 00 & 00 \\
\hline
\end{tabular}

$\mathrm{t} 0=$ Triradius near wrist crease, $\mathrm{t} 2=$ Triradius near centre of palm, $\mathrm{t} 1=$ Triradius between $\mathrm{t} 0$ and $\mathrm{t} 2, \mathrm{t} 1 \mathrm{t} 2=\mathrm{Two}$ Triradii one to another $\mathrm{t} 2, \mathrm{t} 1 \mathrm{t} 2=\mathrm{Two}$ Triradii one $\mathrm{t} 1$ another $\mathrm{t} 2$ 
This TABLE shows the percentage of axial triradii for positions ' $t 0$ ' is $50 \%$, ' $\mathrm{t} 1$ ' is $36 \%$, ' $\mathrm{t} 2$ ' is $4.5 \%$ in mentally retarded males, while in control males, the percentage of axial triradii for positions ' $t 0$ ' is $81 \%$, ' $\mathrm{t} 1$ ' is $15 \%$, ' $\mathrm{t} 2$ ' is $0.5 \%$. In mentally retarded females the percentage of axial triradii for positions ' $\mathrm{t} 0$ ' is $39 \%$, ' $\mathrm{t} 1$ ' is $36 \%$, ' $\mathrm{t} 2$ ' is $4 \%$ whereas in control females, the percentage of axial triradii for positions ' $\mathrm{t} 0$ ' is $78.5 \%$, ' $\mathrm{t} 1$ ' is $13.5 \%$ and ' $\mathrm{t} 2$ ' is $1 \%$

'atd' angle:-

Mean value for 'atd' angle was increased in mentally retarded males(R-51.79 and L-51.03) and females (R-50.15 and L-51.68)as compared to normal males (R-43.77 and L-43.61) and females (R-43.59 and L-43.92) .Overall there is significant increase in 'atd' angle in mentally retarded children when compared with that of controls.

Sydney line:-

There is an increased frequency of Sydney line in MR children (21.75\%) than controls (14\%).

TABLE No. 6:- Frequency distribution of different types of Simian Crease in mentally retarded children \& controls.

\begin{tabular}{|l|l|l|l|l|l|l|l|l|}
\hline \multirow{2}{*}{ TYPES } & \multicolumn{9}{|l|}{ MENTALLY RETARDED } & M & $\mathrm{F}$ & $\mathrm{M}+\mathrm{F}$ & $\%$ & $\mathrm{M}$ & \multicolumn{3}{l|}{ CONTROLS } \\
\cline { 2 - 9 } & 144 & 144 & 218 & 54.50 & 29 & 17 & 46 & 11.50 \\
\hline 2 & 16 & 17 & 35 & 8.75 & 8 & 6 & 14 & 3.50 \\
\hline 3 & 6 & 8 & 14 & 3.50 & 0 & 0 & 0 & 0.00 \\
\hline 4 & 7 & 6 & 13 & 3.25 & 0 & 0 & 0 & 0.00 \\
\hline 5 & 0 & 1 & 1 & 0.25 & 0 & 0 & 0 & 0.00 \\
\hline 6 & 5 & 3 & 8 & 2.00 & 0 & 0 & 0 & 0.00 \\
\hline 7 & 7 & 3 & 10 & 2.50 & 3 & 1 & 4 & 1.00 \\
\hline 8 & 1 & 2 & 4 & 1.00 & 0 & 0 & 0 & 0.00 \\
\hline 9 & 0 & 0 & 0 & 0.00 & 0 & 0 & 0 & 0.00 \\
\hline 10 & 0 & 0 & 0 & 0.00 & 0 & 0 & 0 & 0.00 \\
\hline 11 & 0 & 0 & 0 & 0.00 & 0 & 0 & 0 & 0.00 \\
\hline 12 & 0 & 0 & 0 & 0.00 & 0 & 0 & 0 & 0.00 \\
\hline 13 & 11 & 10 & 21 & 5.25 & 0 & 0 & 0 & 0.00 \\
\hline Total & 197 & 195 & 392 & 91.00 & 40 & 24 & 64 & 16.00 \\
\hline
\end{tabular}

SC - Simian Crease, M - Male, F - Female

TABLE no. 6 shows frequency distribution of different types of Simian crease in mentally retarded children and controls. The table shows high frequency of type ' 1 ' 'in mentally retarded children $(54.5 \%)$ as well as control (11.5\%). Second most common is type ' 2 ' in mentally retarded children $(8.75 \%)$ and controls $(3.5 \%)$ followed by type ' 13 ' which is third most common type in mentally retarded (91\%) than that of controls (16\%). Overall there is more increase in percentage of Simian crease in mentally retarded children $(91 \%)$ than that of controls $(16 \%)$.

\section{Discussion}

The study of various dermatoglyphic features and its composite evaluation has been of value in diagnosing variety of disorders which could be either gross chromosomal or localized genetic. Majority of these disorders have mental retardation as a common and striking feature. Alter \&Bruhel [3], Clare Davison [4], Gupta et al. [6], HemaPurandare, et al. [7] correlated the mental retardation with various dermatoglyphic findings with some positive and major negative relationships.

The selection of cases for evaluation is of importance. It is necessary to conduct all these findings sex wise $\&$ sidewise. Such studies were carried out by Alter \&Bruhel [3]. In our study, features were studied sex wise as well as sidewise.

The fingerprint pattern - The dermal pattern in mentally retarded group shows that ulnar loops occur most frequently than any other fingertip pattern. This relative frequency of ulnar loops in mentally retarded children was also noted by Kher et al [8]; PurandareHema [7]; NiikawaN,et al [9]; Harold Chen[10].

Studies carried out by Alter \& Bruhel [3], Gupta et al [6], and showed that there was no significant difference in frequency pattern.

Our study showed statistically significant decrease in the mean TFRC value in mentally retarded males, which is a very significant finding, while in mentally retarded females, there is no significant difference. The above finding coincides with the observations of Kumar\& Kumar [11], PurandareHema [7]; Simsek S et al [12]; Saralaya V. et al [13]. Some of the authors had not shown such finding. Saksena\&Mathur [14] recorded high TFRC in mentally retarded children as compared to normal. Others include Alter \& Bruhel H [3]; Gupta et al 
[6], did not find any significant difference. There is also decrease in mean value of AFRC in mentally retarded males \& females when compared with normal.

In our study, palmar patterns are found to be significantly increased in fourth interdigital, hypothenar\& third interdigital areas in mentally retarded males, whereas in case of mentally retarded females, the palmar pattern is increased in fourth interdigital\&hypothenar areas when compared with controls. Increased frequency of hypothenar pattern in mentally retarded children was also noted by Hakkinen\&Lundell [15]; Saksena\&Mathur [14]; Niikawa N. et al [9]; Harold Chen [10], found increased pattern in hypothenar\& third interdigital areas.

In the study conducted by PurandareHema et al [7], patterns in second, third \& fourth interdigital areas did not show any variations between the two groups. Alter \&Bruhel [3], found high frequency pattern in second interdigital area in male mentally retarded children. In females, they did not show any significant difference. Similarly Fang, did not find any significant difference between the two groups in third interdigital area pattern. The values of Axial Tiradii in our study show statistical difference which coincides with those obtained by; Hakkinen\& Lundell [15]; Saksena\&Mathur [14]; Chakraborti\&Magotra [16]; Harold Chen [10].

A statistically significant increase in mean value of 'atd' angle in mentally retarded children was seen in our study. Similar findings were reported by Kher et al [8]; Chakraborti\&Magotra [16]; PurandareHema[7] Simsek S. et al [12].

An increased tendency towards palmar creases such as Sydney line \& Simian crease were seen our study which was also reported by other authors like Penrose [2], PurandareHema [7]; Hakkinen\&Lundell [15];\& Harold Chen [10].

\section{Conclusions}

The above study led us to the following conclusions:-

1.1 There is definitely a statistically significant difference in dermatoglyphics patterns in mentally retarded children as compared to healthy control.

1.2 Ulnar loops are most frequently found dermal pattern of finger tips in mentally retarded children, while radial loops are most infrequent.

1.3 Total finger ridge count is low in mentally retarded males than in controls.

1.4 There is significant increase in mean values of 'atd' angle in mentally retarded children.

1.5 Distal displacement of axial triradius was found in mentally retarded children.

1.6 There is an increase frequency of Simian crease and Sydney line in mentally retarded children than control.

\section{Acknowledgements}

We are extremely thankful to Mrs.Chate, Head of "Nandanvan", Home for the Mentally Retarded, Dr. Mrs. Veena Telang Head of the Child Development Center, Dr.Uikey, Head of the Occupational Therapy School, Government Medical College Nagpur, for allowing us to undertake this study work.

We humbly acknowledge the full support and cooperation of all the subjects without whom this study would have been incomplete.

Cummins H. and Midlo, Palmar \& Planter epidermal ridge Configurations, European \& American: Am.J.Phy.Anthroplogy, 9,1926,471-502

[2]. Penrose, Fingerprints Palms\&Chromosomes nature,197,1963,933-938

[3]. Alter M. and Bruhel H, Dermatoglyphics in idiopathic mental retardation, American Journal of Diseases in children, 113, $1967,702-706$

[4]. Clare Davison,Dermatoglyphic in patients with idiopathic severe subnormality and Genetic studies in mental subnormality, British Journal of Psychiatry special publication, 8, 1973, 21-24.

[5]. Cummins \&Midlo, Fingerprints in Palms \&Soles, An introduction to Dermatoglyphics, Dovar Pub. INC New York, 1961.

[6]. Gupta A.R, Sethi B.B. and Singh M.P, A Dermatoglyphic study in mental subnormality, Journal of Associations of Physicians of India, 24(4), 1976, 219-223.

[7]. Purandare H, Atre P.R. \& Vare A.M, Dermatoglyphic features in mentally retarded children,Anat.Soc. of IndiaVol.27,1978,3

[8]. Kher, Indurkar M.B., Dermatoglyphics in Pediatric practice, Indian journal of Medical Science Vol.25, 1971,618

[9]. Niikawa N and Kuroki Y, Kabuki make up syndrome, American journal of Medical Genetics, 31, 1988, 565-589.

[10]. Chen Harold, The simian line, Medical Journal, Sep Vol. II, 9, 2001, 134-139.

[11]. Kumar and Kumar, Dermatoglyphic analysis as a diagnostic tool in Down's syndrome, Indian Journal of Pediatrics, 39,1972, 39.

[12]. Simsek S, Karakaya N andFistik T, Dermatoglyphic Analysis in children with cerebral palsy, Neurobiology ,6(i), 1998,373-380

[13]. Saralaya and Rao C.P., Evaluation of palmar digital ridge pattern frequencies in young mentally retarded patients, Journal of Anatomy Society of India, 50(1), 2001, 69-98.

[14]. Saksena P \&Mathur P P, Evaluation of Dermatoglyphics in Mental deficiency, Indian Journal of Pediatrics,9,1972,627-628

[15]. Hakkinen J\&Lundell E, A Dermatoglyphic study of the palms of mongoloids imbeciles \& normal subjects, Acta Pediatrica, 48, 1959, 379-382.

[16]. Chakraborti \& Magotra, Dermatoglyphics in clinical pediatrics, Indian Pediatrics, 13, 1976, 355-358. 